Available online at: http://proceeding.rsfpress.com/index.php/ic-smart/index

Proceeding on International Conference of Science Management Art Research Technology

(IC-SMART)

Volume 1 Number 1 (2020): 44-48

\title{
Monitoring of The Fertility Ambon Bay Using Aqua MODIS Satellite Imagery After Launching of Save Ambon Bay Program
}

\author{
Rina Luciane Manuhutu' ${ }^{1}$, Samy Junus Litiloly², Rina Latuconsina ${ }^{1}$, Luwis H. \\ Laisina $^{1}$, Sefnath Johanes Wattimena ${ }^{1}$ \\ ${ }^{1}$ Teknik Elektro, Politeknik Negeri Ambon, Country Indonesia; \\ ${ }^{2}$ Teknik Mesin, Universitas Pattimura, Country Indonesia \\ E-mail address rinamanuhutu@gmail.com; E-mail address sj.litiloly@fatek.unpatti.ac.id; E-mail \\ address rinawalconz@gmail.com; E-mail address Luwis.polnam@gmail.com; -mail address \\ ephynaulu@yahoo.co.id
}

\begin{abstract}
Ambon Bay pollution had become a problem when in 1994, there was an algae bloom, which caused 34 people to get sick, and 3 of them died from eating shellfish that had been contaminated with poison from toxic phytoplankton. Since then, various mass media have reviewed and commented on the quality of the Ambon Bay waters. The highlight of the Ambon Bay pollution occurred when in November 2012, the Director-General of Marine Affairs and Small Islands (KP3K) of the Ministry of Marine Affairs and Fisheries (KKP) at that time, Eko Radiyanto, personally admitted that he was concerned about the pollution that occurred in Ambon Bay. Since then, the program "Kalesang Teluk Ambon or Save Ambon Bay" has been launched. The problem that has arisen is how the condition of the fertility of Ambon Bay since the save ambon Bay program was launched to date. The purpose of this study was to monitor the fertility of the Ambon bay in the last eight years since the Save Ambon bay program was launched. Monitoring was carried out from 2013 to 2020 by utilizing remote sensing technology by processing Aqua Modis satellite image data to determine the value of chlorophyll-a distribution as an indicator of water fertility. The results showed that in the first year of the Ambon Bay save the program, there was an increase in the fertility of Ambon Bay from 0.39 to $0.90 \mathrm{mg} / \mathrm{m} 3$, but after that, there was a decrease from year to year except in 2020, fertility increased dramatically from 0.31 to $1.00 \mathrm{mg} / \mathrm{m} 3$.
\end{abstract}

Keywords: Ambon bay, Aqua Modis, chlorophyll-a

\section{INTRODUCTION}

This is an open access article under the CC-BY-NC license

Ambon Bay is part of Ambon Island which is geographically located at the position 128o04'15" 128014'25" BT dan 3037'55" - 3037'45"' LS (Edward, 1996). Ambon Bay has several functions, namely as an area for capture fisheries and aquaculture, a port for the Indonesian Navy and Polairud base, a port for PT Pelni ships, traditional inter-island ships, ferry crossings, PT. Pertamina, sea transportation routes, places for disposal of waste oil and hot water by PLN, docks where ship repairs, sand, and stone mining sites, conservation areas, recreation, and sports areas, even as final disposal sites for community waste, both garbage and other waste (Debby et.al, 2009). The function 
Proceeding on International Conference of Science Management Art Research Technology (IC-SMART), Vol. 1 (1), 44-48

Monitoring of The Fertility Ambon Bay Using Aqua MODIS Satellite Imagery After Launching of Save Ambon Bay Program

Rina Luciane Manuhutu, Samy Junus Litiloly, Rina Latuconsina, Luwis H. Laisina, Sefnath Johanes Wattimena

description of Ambon bay clearly shows that the condition of the Ambon bay area has been used for various activities, including the pollution of Ambon Bay. The location of the Ambon city market, which is on the coast of Ambon bay, also has an adverse impact because the garbage is dumped into the sea. Deforestation for development also causes sedimentation, which results in reduced or loss of marine biodiversity.

Ambon Bay pollution had become a problem when in 1994, there was an algae bloom, which caused 34 people to get sick, and 3 of them died from eating shellfish that had been contaminated with poison from toxic phytoplankton (Hanung, 2012). Since then, various mass media have reviewed and commented on the quality of the Ambon Bay waters. The highlight of the Ambon Bay pollution occurred when in November 2012, the Director-General of Marine Affairs and Small Islands (KP3K) of the Ministry of Marine Affairs and Fisheries (KKP) at that time, Eko Radiyanto, personally admitted that he was concerned about the pollution that occurred in Ambon Bay (Kompas, 2012). Since then, the program Save Ambon Bay or "Kalesang Teluk Ambon" has been launched. From the description above, the problem that arises is how the condition of the Ambon Bay after the save Ambon bay program was launched until this time.

The research objective was to monitor the fertility of Ambon bay in the last eight years since the save Ambon bay program was launched from 2013 to 2020. In order to know the current condition of the fertility of Ambon Bay, to know the success or failure of government efforts to reduce the level of pollution in Ambon Bay. The results of this study will be very useful for the Ambon city government in making further policies to overcome the pollution of Ambon Bay.

\section{LITERATURE REVIEW}

\subsection{Aqua MODIS satellites}

MODIS (Moderate Resolution Imaging Spectroradiometer) is one of the main instruments in the Earth Observing System (EOS) Aqua satellite, which is part of the United States space program, the National Aeronautics and Space Administration (NASA). Aqua MODIS was successfully launched on May 4, 2002. Several uses of Aqua MODIS image data are to determine chlorophyll content in waters, sea surface temperature and also to determine potential fishing zones

Aqua MODIS orbits the earth every day in harmony with the sun (sun-synchronous) at an altitude of $705 \mathrm{~km}$ with an ascending node system (south to north). Each time it passes, the satellite provides a viewing width of $2330 \mathrm{~km}$, and the resulting image has three spatial resolutions, namely $250 \mathrm{~m}$ (bands 1-2), $500 \mathrm{~m}$ (bands 3-7), $1000 \mathrm{~m}$ (bands 8-36).

\subsection{Phytoplankton and chlorophyll a}

Phytoplankton is microscopic marine plants, and their movements are influenced by their surrounding environment. All types of phytoplankton have chlorophyll or green leaf grains so that they are able to carry out the photosynthesis process to convert inorganic substances into organic substances which are needed by other organisms in the sea. There are three kinds of chlorophyll, namely chlorophyll-a, chlorophyll-b, and chlorophyll-c. Among the three chlorophylls, chlorophylla is contained by most phytoplankton species that live in the sea (Sarapang, 2006).

The distribution of chlorophyll-a in the sea varies geographically and is based on water depth. These variations are caused by differences in light intensity, the sun, and the concentration of nutrients in the water. In the sea, the concentration of chlorophyll-a is higher in coastal and coastal waters, and lower in offshore waters. The high distribution of chlorophyll-a concentrations in coastal and coastal 
Proceeding on International Conference of Science Management Art Research Technology (IC-SMART), Vol. 1 (1), 44-48

Monitoring of The Fertility Ambon Bay Using Aqua MODIS Satellite Imagery After Launching of Save Ambon Bay Program

Rina Luciane Manuhutu, Samy Junus Litiloly, Rina Latuconsina, Luwis H. Laisina, Sefnath Johanes Wattimena

waters is due to a large supply of nutrients through run-off from land, while the low concentration of chlorophyll-a in offshore waters is due to the absence of direct nutrient supply from the land.

The average value of chlorophyll content in Indonesian waters is $0.19 \mathrm{mg} / \mathrm{m} 3$ to $0.24 \mathrm{mg} / \mathrm{m} 3$. There is abundant pelagic fish in areas with chlorophyll content of $0.8-2.0 \mathrm{mg} / \mathrm{m} 3$ (Hendiarti et.al, 2005).

\section{RESEARCH METHODOLOGY}

Aqua MODIS image data in the study is monthly level 3 image data downloaded from https://oceancolor.gsfc.nasa.gov/. The data to be used is 8 Aqua MODIS image data selected from 2013 to 2020, namely data on August 17 each year, except for 2020 data, which is data on August 9, 2020.

Aqua MODIS level 3 image data is processed by cutting the image according to the research location, namely Ambon Bay, and then processed to get the value of chlorophyll-a in the form of image data and statistical data using the SEADAS 7.5.3 open-source application.

\section{FINDING AND DISCUSSION}

From the data in Figure 1, it can be seen that the Aqua MODIS data dated August 17, 2013, shows the average value of chlorophyll-a in Ambon Bay is $0.39 \mathrm{mg} / \mathrm{m} 3$ with a minimum value of $0.35 \mathrm{mg}$ $/ \mathrm{m} 3$ and a maximum value of $0.5 \mathrm{mg} / \mathrm{m} 3$.

Aqua MODIS data dated August 17, 2014, shows that the average value of chlorophyll-a in Ambon Bay is $0.90 \mathrm{mg} / \mathrm{m} 3$ with a minimum value of $0.55 \mathrm{mg} / \mathrm{m} 3$ and a maximum value of $2.56 \mathrm{mg} / \mathrm{m} 3$.

Aqua MODIS data dated August 17, 2015, shows the average value of chlorophyll-a in Ambon Bay is $0.76 \mathrm{mg} / \mathrm{m} 3$ with a minimum value of $0.46 \mathrm{mg} / \mathrm{m} 3$ and a maximum value of $2.47 \mathrm{mg} / \mathrm{m} 3$.

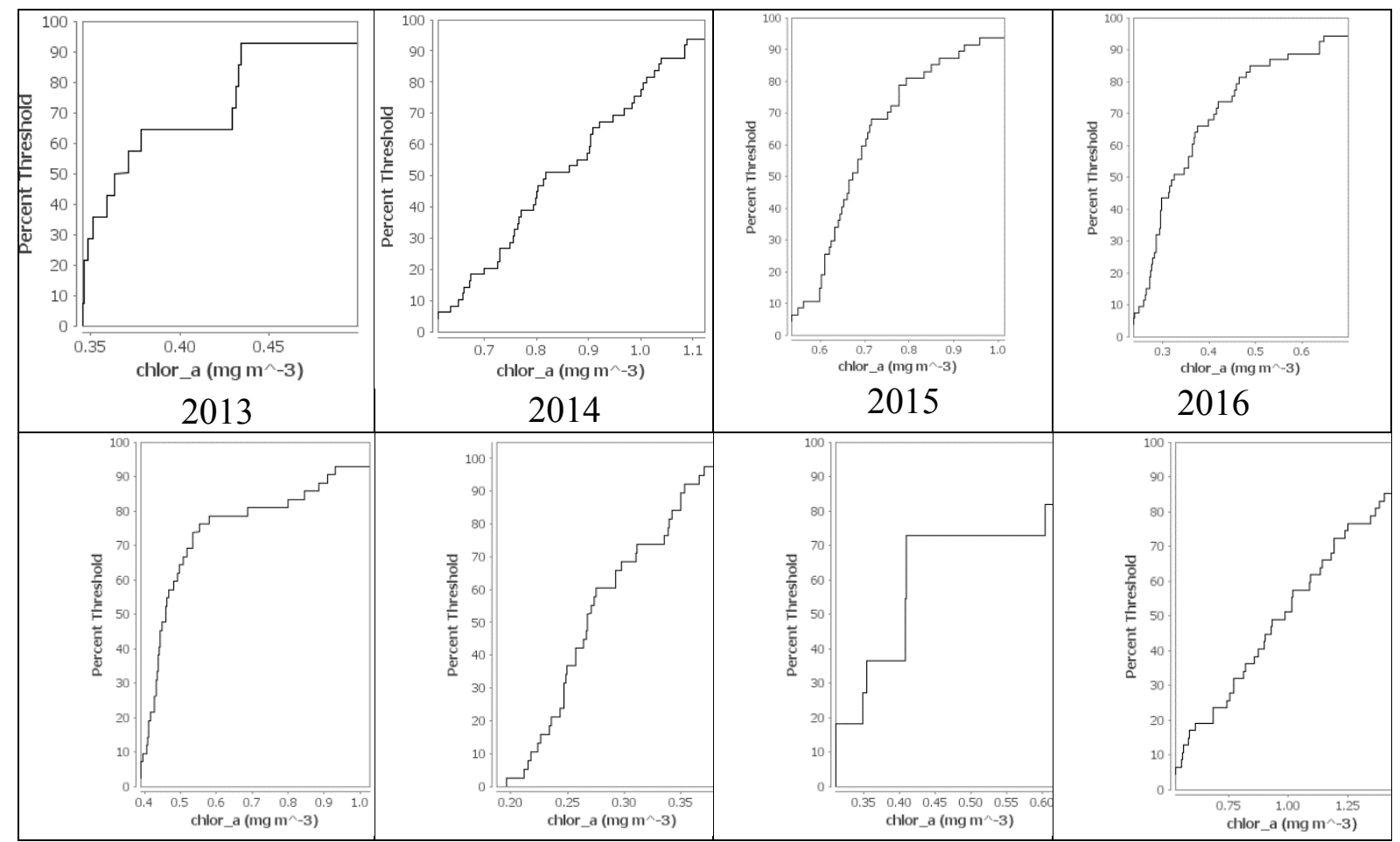


Proceeding on International Conference of Science Management Art Research Technology (IC-SMART), Vol. 1 (1), 44-48

Monitoring of The Fertility Ambon Bay Using Aqua MODIS Satellite Imagery After Launching of Save Ambon Bay Program

Rina Luciane Manuhutu, Samy Junus Litiloly, Rina Latuconsina, Luwis H. Laisina, Sefnath Johanes Wattimena

\begin{tabular}{l|l|l|r}
2017 & 2018 & 2019 & 2020
\end{tabular}

Figure 1. Statistical data for chlorophyll-a in Ambon Bay, 2013 - 2020

Aqua MODIS data dated August 17, 2016, shows the average value of chlorophyll-a in Ambon Bay is $0.23 \mathrm{mg} / \mathrm{m} 3$ with a minimum value of $0.73 \mathrm{mg} / \mathrm{m} 3$ and a maximum value of $2.56 \mathrm{mg} / \mathrm{m} 3$.

Aqua MODIS data dated August 17, 2017, shows the average value of chlorophyll-a in Ambon Bay is $0.56 \mathrm{mg} / \mathrm{m} 3$ with a minimum value of $0.38 \mathrm{mg} / \mathrm{m} 3$ and a maximum value of $1.30 \mathrm{mg} / \mathrm{m} 3$.

Aqua MODIS data dated August 17, 2018, shows the average value of chlorophyll-a in Ambon Bay is $0.28 \mathrm{mg} / \mathrm{m} 3$ with a minimum value of $0.38 \mathrm{mg} / \mathrm{m} 3$ and a maximum value of $0.38 \mathrm{mg} / \mathrm{m} 3$.

Aqua MODIS data dated August 17, 2019, shows the average value of chlorophyll-a in Ambon Bay is $0.31 \mathrm{mg} / \mathrm{m} 3$ with a minimum value of $0.31 \mathrm{mg} / \mathrm{m} 3$ and a maximum value of $0.63 \mathrm{mg} / \mathrm{m} 3$.

Aqua MODIS data dated August 9, 2020, shows the average value of chlorophyll-a in Ambon Bay is $1.00 \mathrm{mg} / \mathrm{m} 3$ with a minimum value of $0.45 \mathrm{mg} / \mathrm{m} 3$ and a maximum value of $1.72 \mathrm{mg} / \mathrm{m} 3$.

The data above are made in table 1 and displayed in the chart in Figure 2.

Table 1. Chlorophyll a data in Ambon Bay $\left(\mathrm{mg} \mathrm{m}^{-3}\right)$

\begin{tabular}{|c|c|c|c|}
\hline Days/Years & Mean & Min & Max \\
\hline 17 August 2013 & 0.39 & 0.35 & 0.50 \\
\hline 17 August 2014 & 0.90 & 0.55 & 2.56 \\
\hline 17 August 2015 & 0.76 & 0.46 & 2.47 \\
\hline 17 August 2016 & 0.38 & 0.23 & 0.73 \\
\hline 17 August 2017 & 0.56 & 0.38 & 1.30 \\
\hline 17 August 2018 & 0.28 & 0.38 & 0.38 \\
\hline 17 August 2019 & 0.31 & 0.31 & 0.63 \\
\hline 9 August 2020 & 1.00 & 0.45 & 1.72 \\
\hline
\end{tabular}

From Figure 2, it can be seen that the average fertility of Teluk Ambon only increased in the first year after the Ambon Bay save program so that the fertility of Ambon Bay continued to decline and increased slightly in 2017, but in 2018 it fell again and increased sharply in 2020 


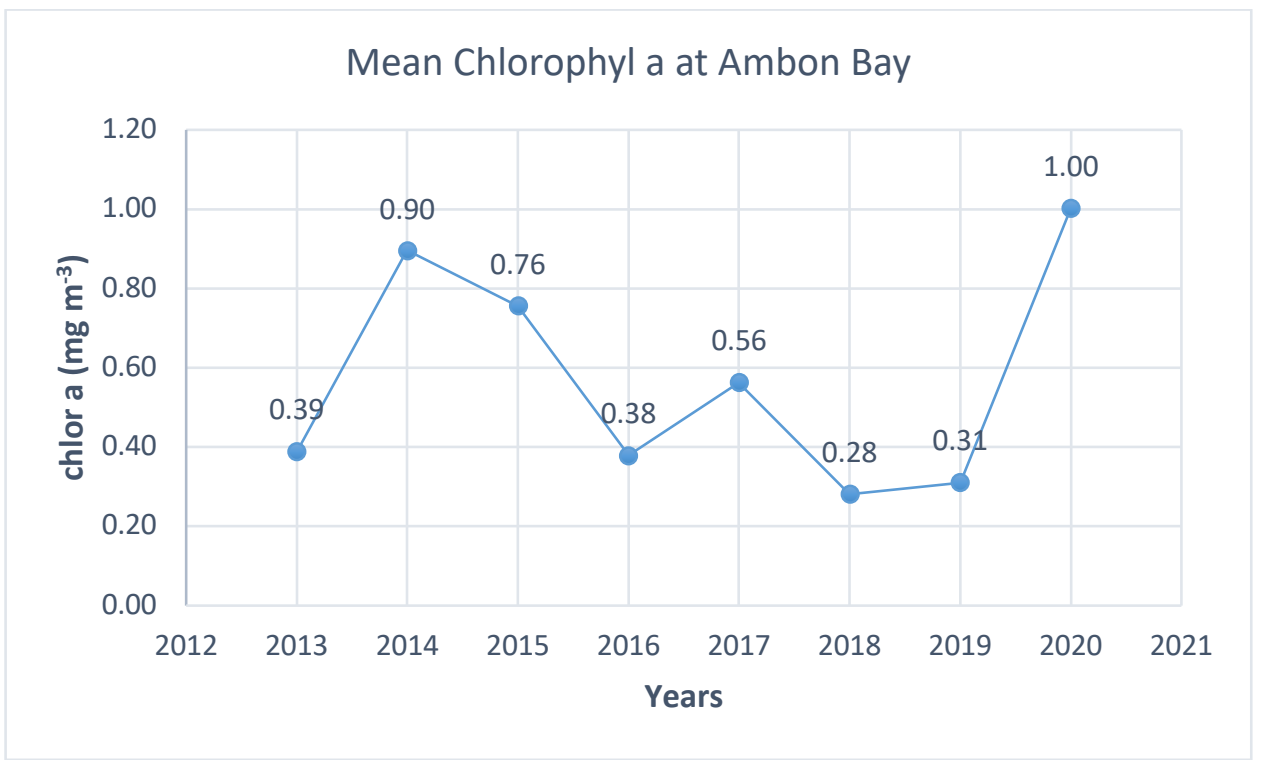

Figure 2. Mean Chlorophyll-a in Ambon Bay 2013 - 2020

\section{CONCLUSION AND FURTHER RESEARCH}

1.The results show that in the first year of the Ambon Bay save the program, there was an increase in the fertility of Ambon Bay from 0.39 to $0.90 \mathrm{mg} / \mathrm{m} 3$, but after that, there was a decrease from year to year except in 2020 , the fertility increased from 0.31 to $1.00 \mathrm{mg} / \mathrm{m} 3$.

2.The Save Ambon bay program has shown success in the first year after the Save Ambon bay program was launched.

3.Increasing fertility in 2020 can be followed up with new research to find out the causes.

\section{REFERENCES}

Situs Kota Ambon. 2013. Selamatkan teluk Ambon. http://www.ambon.go.id/selamatkan-telukambon-pemkot-ambon-bersama-faperik-unpatti-gelar-seminar-ilmiah/

Debby, A. J. S., Adiwilaga, E. M., Dahuri, R., Muchsin, I., \& Effendi, H. (2009). Sebaran spasial luasan area tercemar dan analisis beban pencemaran bahan organik pada perairan Teluk Ambon Dalam.

Edward. 1996. Kualitas Perairan Teluk Ambon. Tesis. Perpustakaan Universitas Indonesia. http://lib.ui.ac.id/opac/ui/detail.jsp?id=80212\&lokasi=lokal

Hanung A. M. dan Isdy S. 2012. Jurnal Omni-Akuatika Vol. XI No.14:28-40

Kompas.com. Pencemaran teluk Ambon Kian Parah. 2012. http://regional.kompas.com/read/2012/11/01/14523112/Pencemaran.Teluk.Ambon.Kian.Parah.

Sarapang R. N. 2006. Penentuan Zona Potensial Penangkapan Ikan menggunakan citra satelit MODIS. Skripsi tidak dipublikasikan. Bandung: ITB.

Hendiarti, N., Aldrian, E., AMRI, K., ANDIASTUTI, R., SACHOEMAR, S. I., \& WAHYONO, I. B. (2005). Seasonal variation of pelagic fish catch around Java. Oceanography, 18(4), 112-123. https://oceancolor.gsfc.nasa.gov/.

https://seadas.gsfc.nasa.gov/ 